Research Article

\title{
Management of buerger's disease (TAO) with ilizarov (A Retrospective Study of 18 Cases)
}

Volume 3 Issue 4 - 2015

\section{Introduction}

Buerger's Disease (Thrombo Angiitis Obliterans- TAO) is an episodic, segmental inflammatory thrombotic disease that most commonly affects the arteries and superficial veins resulting signs and symptoms of ischaemia of both upper and lower limbs usually in men between 25 to 45 years of age. The etiology of TAO is unknown, seen very commonly in smokers. ${ }^{1,2}$ The standard treatment modalities include, discontinue using tobacco, food care, calcium channel blockers, prostaglandin analogues, revascularization, lumbar sympathectomy, amputation- if all the above fails.

\section{Materials and methods}

All the 18 patients, were male, a chronic smoker.

1. C/C: Discoloration of foot associated with blebs, coldness and swelling of the foot. All patients had severe nocturnal rest pain.

2. O/E: Popliteal and distal pulses were not palpable in the foot. Mild discoloration was present and popliteal and distal pulses were feeble.

\section{Investigations}

Arterial Doppler study of the limb showed atheroseterotic disease of anterior and posterior tibial artery with numerous collaterals in the lower leg.

\section{Surgical procedure}

The surgical procedure was performed at the antero-lateral part of the tibia approximately $12 \mathrm{~cm}$ long and $2 \mathrm{~cm}$ wide. The Ilizarov device consists of 2 rings and 4-6 olive wires linked to a lateral plate. Osteotomy done above and below and below the olive wires meticulously. The tibial section has been moved approx. $1 \mathrm{~mm} /$ day for 3 weeks. ${ }^{1-4}$ The clinical status improved within a few weeks. Cure of trophic ulcers observed and no more pain. Arteriogram on the 2nd month improved circulatory result.

In view of the above symptoms Ilizarov external fixator was applied in the right or left leg with vertical corticotomy of the proximal and middle $1 / 3$ of the tibia, distraction continued for 3 weeks. Ilizarov external fixator was removal after 8-10 weeks depending upon the cases. After removal of Ilizarov apparatus plaster cast was applied for 3 weeks. The treatment of TAO and limb salvage was successful by this method. Ilizarov external fixator in the proximal half of the tibia followed by distraction of this procedure creates neovascularization in blood circulation of the lower limbs, which relieves the patient's pain and ischaemic symptoms. ${ }^{5-7}$

\section{Observation and results}

Presently all the patients are doing well except of 2 cases, in which amputation was done, due to inappropriate selection of the patient.

\author{
Bari MM,' Shahidul Islam, ${ }^{2}$ Rouf AHMA, ${ }^{3}$ \\ Mahfuzer Rahman² \\ 'Chief Consultant, Bari-llizarov Orthopaedic Centre,Visiting and \\ Honored Prof., Russian Ilizarov Scientific Centre, \\ Russia \\ ${ }^{2}$ Bari-llizarov Orthopaedic Centre, Bangladesh \\ ${ }_{3}^{3}$ Jessore Medical College \& Hospital, Bangladesh
}

Correspondence: Mofakhkharul Bari, Chief Consultant, Barillizarov Orthopaedic Centre,Visiting and Honored Professor, Russian Ilizarov Scientific Centre, Kurgan, Tel +88 01819211595 , Email bari.illizarov31@gmail.com

Received: October 08, 2015 | Published: October 15, 2015

Almost all the patients nocturnal rest pain had totally disappeared for the last 5 years.

\section{Results}

A 44 years old male suffers from TAO (Stage 3) of the lower extremities. The sequelae are most prominent on the left with permanent pain and major trophic ulcer over the left great toe. His walking distance was a quarter km. 16 months before he had a bilateral lumbar sympathectomy which could not improve the situation (Table 1 \& Figure 1).

Table I Study period January 2003 to January 2013

\begin{tabular}{ll}
\hline (I I Years) & Cases \\
$\begin{array}{l}\text { Relived of pain } \\
\text { Partial relief }\end{array}$ & $\begin{array}{l}15 \text { cases } \\
\text { I case }\end{array}$ \\
$\begin{array}{l}\text { Amputation (due to gangrene) } \\
\text { improper selection of the patient }\end{array}$ & 2 cases
\end{tabular}

\section{Pre-surgery arteriogram confirmed}

Extreme degree of involvement- left anterior and posterior arteries are totally occluded at their proximal part. A surgical procedure was performed on 22nd March, 2009. Sequential follow up 1234 (Figure $2 \& 3)$.

\section{Pre-surgery arteriogram confirmed}

Extreme degree of involvement- left anterior and posterior arteries are totally occluded at their proximal part. A surgical procedure was performed on 22nd March, 2009. Sequential follow up 1234 (Figure $2 \& 3)$.

\section{Discussion and conclusion}

Ilizarov external fixator in the management of TAO and limb salvage is an excellent procedure which serves four purposes. A. Law of tension-stress "Slow and steady traction on a living tissue
creates a stress that stimulates metabolic activation and maintains 
regeneration and active growth of that tissue (bone, muscles, fascia, tendon, nerve, vessels, skin and its appendages)".

B. Corticotomy- Low energy osteotomy with the preservation of periosteum, endosteum and bone marrow.

C. Distraction osteogenesis $(0.25 \mathrm{~mm} \times 4)$-Mechanical induction of bony surfaces that is gradually pulled apart in a controlled manner.

D. Myriads of ring fixators- More than 700 configurations are available. a
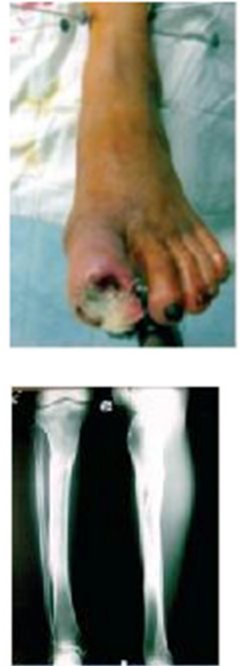
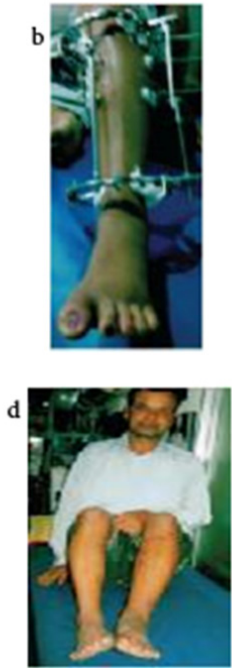

Figure I Case I.

a. Before treatment

b. Trophic ulcer of the great toe showing improvement after $1 \frac{1}{2}$ months

c. Widening of Tibia after removal of the llizarov fixator.

d. After treatment. a
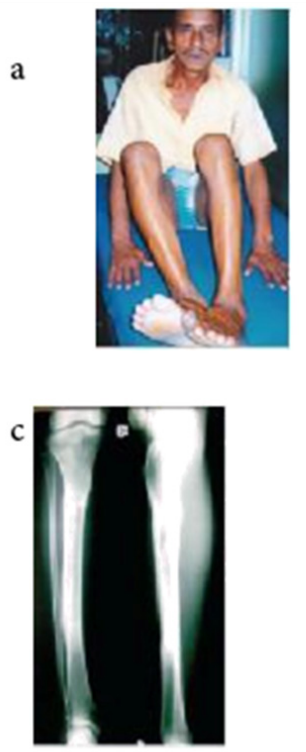
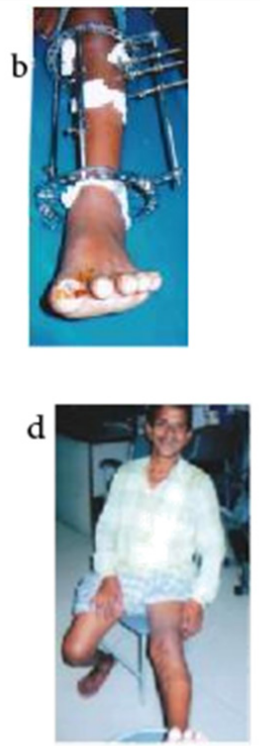

Figure 2 Case 2.

a. TAO in a 44 yrs Old man.

b. During treatment with llizarov.

c. Widening of Tibia after removal of the llizarov fixator.

d. After treatment great toe ulcer is cured.

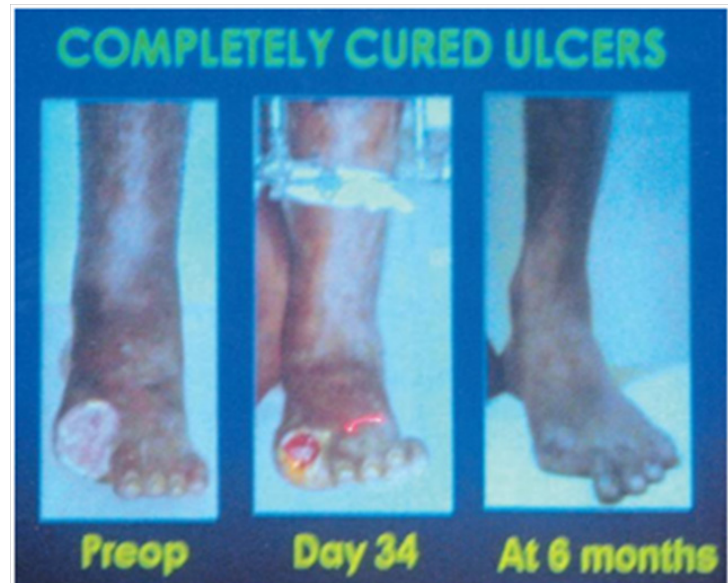

Figure 3 Case 3. completely cured ulcers.

Corticotomy of the proximal and middle tibia followed by distraction and regeneration increases the girth of the tibia, also increases the blood circulation of the lower limbs, relieving the pain. The cases reported here was posted for amputation by the vascular surgeons, who did not have any other option for treatment. Hence we, re-affirm that Academician Prof. Ilizarov's method of treatment does help some patients suffering from TAO. ${ }^{8-10}$

\section{Acknowledgments}

None.

\section{Conflicts of interest}

None.

\section{References}

1. Baums MH, Kahl E, Schultz W, et al. Clinical outcome of the arthroscopic management of sports-related "anterior ankle pain": A prospective study. Knee Surg Sports Traumatol Arthrosc. 2006;14(5):482-486.

2. Ilizarov GA. Transosseous Osteosynthesis theoretical and clinical aspects of the regeneration and growth of tissue. Springer-Verlag Berlin Heidelberg, Germany. 1992;pp.800.

3. Bari MM. A color atlas of limb lengthening, surgical reconstruction and deformity correction by Ilizarov technique. 2013;pp.368-375.

4. Ilizarov GA. The principles of the Ilizarov Method. Bull Hosp Jt Diseases. 1988;48(1):1-11.

5. Ilizarov GA, Frankel GH. The Ilizarov External Fixator, A Physiologic Method of Orthopaedic Reconstruction and Skeletal Correction. Ortho Rev. 1988;17(11):1142-1154.

6. Ilizarov GA. The Tension-Stress Effect on the Genesis and Growth of Tissues: Part. II. The Influence of the Rate and Frequency of Distraction. Clin Ortho Rel Res. 1989;239:263-285.

7. Ilizarov GA. Experimental Studies of Bone Elongation. In: Coombs R, et al. (Eds.), External Fixation and Functional Bracing, Orthotext, London, UK. 1989.

8. Ilizarov GA. Clinical Application of the Tension-Stress Effect for Limb Lengthening. Clin Ortho Rel Res. 1990;250:8-26.

9. Movshovich IA. Orthopaedic surgery. Moscow. 1983.

10. Paley D. Problems, Obstacles, and complications of Limb Lengthening by the Ilizarov Technique. Clin Ortho Rel Res. 1990;250:81-104.

11. Wolfson N, Hearn TC, Thomason JJ, et al. Force and Stiffness Changes During Ilizarov Leg Lengthening. Clin Ortho Rel Res. 1990;250:58-60. 